\title{
ROLE OF PRE-OPERATIVE SELECTIVE ARTERIAL EMBOLIZATION OF RENAL TUMORS IN NEPHRON-SPARING SURGERY: A PILOT STUDY.
}

\author{
Abdalla Ahmed, Mohamed Elgharib, Mahmoud Ahmed, Ahmed Farouk and \\ Mohamed Shaaban.
}

\author{
${ }^{1}$ Department of Urology, Faculty \\ of Medicine, Ain Shams \\ University, Cairo, Egypt. \\ Corresponding Author: \\ Mohamed Ahmed Shaaban \\ Mobile: (+2) 01005683861 \\ E-mail: \\ Dr.MShaaban83@gmail.com \\ Received : 24/5/2020 \\ Accepted: 11/6/2020
}

Online ISSN: 2735-3540

\begin{abstract}
:
Background: Partial nephrectomy (PN) has emerged as a greatly underutilized procedure that is often feasible given adequate surgeon expertise. No consensus on the use of renal artery embolization (RAE) has been fashioned due to the small number of prospective studies comparing surgical resection combined with preoperative embolization versus surgery alone.
\end{abstract}

Aim of the Work: to evaluate the beneficial role of preoperative selective arterial embolization of renal tumors amenable for nephron-sparing surgery (NSS) in enhancing intra-operative challenging difficulties such as: decreasing blood loss and transfusion requirements, decreasing operative time, facilitating tumor dissection and replacing ischemic techniques.

Patients and Methods: Overall, a total of 20 patients with renal masses amenable for nephron-sparing surgery were included in our study. PN after selective pre-operative RAE of the tumor feeding vessels were performed for all patients without renal ischemia. Perioperative data as operative time, blood loss and transfusion requirements were recorded, correlated and statistically analyzed.

Results: In all patients, 2 had significant intra-operative blood loss and required blood transfusion. Patients demographics didn't affect the results. Tumor data had no significant statistical effect on the results. The most important parameter was whether embolization was complete or incomplete.

Conclusion: Benefits of RAE in the preoperative setting include a decrease in operative time and blood loss and creation of a tissue plane of edema facilitating dissection. To date, RAE has not been evaluated in a randomized controlled setting which has contributed to its underutilization

Keywords: Partial Nephrectomy, Renal Artery Embolization, Operative Time, Blood Loss.

\section{INTRODUCTION:}

Renal cell carcinoma (RCC) is the most common malignant renal tumor, comprising an estimated incidence of 2 to $3 \%$ of all malignancies. It is considered the 10th leading cause of cancer death in adult males in the United States with an estimated
64,770 newly-diagnosed cases and 13,570 disease-related deaths in $2012^{(1)}$.

For localized RCC, surgical resection has been approved as the treatment of choice. Partial nephrectomy (PN) to preserve renal function is preferred over radical nephrectomy (RN) if technically feasible 
and has been shown not to compromise survival outcomes ${ }^{(2)}$.

Renal artery embolization (RAE) had been only used as a palliative therapy in patients with unresectable tumor or who are poor surgical candidates, and treatment of hemorrhagic complications, including spontaneous rupture of previously undiagnosed tumor. With growing experience, improving imaging modalities and technical advances including the introduction of more precise embolic agents and smaller delivery catheters, RAE has been increasingly used to augment surgical resection of renal tumors $^{(3)}$.

Benefits of renal artery embolization in the preoperative setting include a decrease in perioperative blood loss, creation of a tissue plane of edema facilitating dissection, and reduction in tumor bulk including extent of vascular thrombus, when present. Additionally, some evidence suggests that preoperative embolization of RCC is associated with improved mortality rates when compared with surgical treatment alone ${ }^{(4)}$.

\section{AIM OF THE STUDY:}

The aim of this work is to evaluate the beneficial role of pre-operative selective arterial embolization of renal tumors amenable for nephron-sparing surgery in enhancing intra-operative challenging difficulties such as: decreasing blood loss and transfusion requirements, decreasing operative time, facilitating tumor dissection and replacing ischemic techniques. Also, to evaluate the potential benefit of such technique in expanding the inclusion criteria of renal tumors amenable for nephronsparing surgery.

\section{PATIENTS AND METHODS:}

Between January 2016 and January 2020, 20 patients were included in this single-center study implemented in Ain shams university hospitals. Inclusion criteria were patients aged 20-65 yrs, with renal tumors $\leq 7 \mathrm{~cm}$ in the biggest dimensions, involving less than $50 \%$ of the renal tissue, with selective dominant feeding artery on angiography. Exclusion criteria were patients with renal tumors $>7 \mathrm{~cm}$, in a single kidney or involving more than $50 \%$ of the renal tissue, with no selective dominant feeding artery on angiography where selective dominant feeding artery was defined as one of the following branches of the renal artery (apical, upper, middle, lower branches of anterior segmental artery, posterior segmental artery or smaller).

Eligible patients had been consented after informative counseling. Detailed medical and surgical history with careful physical examination were obtained.

Percutaneous selective arterial embolization of renal tumors had been performed under local anesthesia and sedation in Interventional Radiology Unit in Ain shams university hospitals 24 hrs before operation. Post-embolization renal angiography films to confirm complete closure of the feeding artery were routinely obtained.

All patients underwent surgical resection of renal tumors in the operating theatre of Urology Department in Ain shams university hospitals under general anesthesia, via an open surgical approach, without using any ischemic technique. Intraoperative data as blood loss amount, operative time and blood transfusion requirements were properly recorded. Postoperative data regarding vital signs, urine output and blood tests as serum hemoglobin and creatinine were recorded.

\section{Statistical methodology:}

Data were collected, revised, coded and entered to the Statistical Package for Social Science (IBM SPSS) version 23. The quantitative data were presented as mean, standard deviations and ranges when 
parametric qualitative data were presented as numbers and percentages. The comparison between groups regarding qualitative data was done by using Chi-square test. The comparison between two independent groups with quantitative data and parametric distribution were done by using Independent t-test while the comparison between two paired groups with quantitative data and parametric distribution were done by using Paired t-test.

The comparison between more than two independent groups with quantitative data and parametric distribution were done by using One Way ANOVA. Pearson correlation coefficients were used to assess the correlation between two quantitative parameters in the same group. The confidence interval was set to $95 \%$ and the margin of error accepted was set to $5 \%$. So, the $\mathrm{p}$-value was considered significant as the following:

$(\mathrm{P}>0.05:$ Non significant, $\mathrm{P}<0.05$ : Significant, $\mathrm{P}<0.01$ : Highly significant).

\section{RESULTS:}

Overall, 20 patients underwent PN after selective RAE of tumor feeding branches. Patients' demographics are reported in table (1).

Table (1): Distribution of age, gender and family history of studied patients.

\begin{tabular}{|l|c|c|}
\hline Patients characteristics & No. $=20$ \\
\hline \multirow{2}{*}{ Age } & Mean \pm SD & $47.15 \pm 11.88$ \\
\cline { 2 - 3 } & Range & $17-65$ \\
\cline { 2 - 3 } & Male & $15(75.0 \%)$ \\
\hline \multirow{2}{*}{ Family History } & Female & $2(25.0 \%)$ \\
\cline { 2 - 3 } & Negative & $18(90.0 \%)$ \\
\cline { 2 - 3 } & Positive & $2(10.0 \%)$ \\
\hline
\end{tabular}

Tumors' characteristics are reported in table (2) where endophytic growth patterns are defined in tumors with more than $50 \%$ of size involved within renal parenchyma while exophytic growth patterns are defined in tumors with less than $50 \%$ of size involved within renal parenchyma.

Table (2): Tumors' characteristics

\begin{tabular}{|l|c|c|}
\hline Tumor data & No. $=20$ \\
\hline \multirow{2}{*}{ Size } & Mean \pm SD & $5.44 \pm 1.07$ \\
\cline { 2 - 3 } & Range & $3.5-7$ \\
\hline \multirow{3}{*}{ Site } & Upper Pole & $7(35.0 \%)$ \\
\cline { 2 - 3 } & Lower Pole & $7(35.0 \%)$ \\
\cline { 2 - 3 } & Midzone & $6(30.0 \%)$ \\
\hline \multirow{2}{*}{ Main Growth Pattern } & EndoPhytic & $8(40.0 \%)$ \\
\cline { 2 - 3 } & ExoPhytic & $12(60.0 \%)$ \\
\hline Dominant Feeding artery & Single & $13(65.0 \%)$ \\
\cline { 2 - 3 } & Multiple & $7(35.0 \%)$ \\
\hline
\end{tabular}

Operative data are reported in table (3). Patients' intraoperative vital profiles showed No significant blood loss except for only 2 cases which required blood transfusion. no significant drop throughout the study. 
Table (3): Operative data.

\begin{tabular}{|l|c|c|}
\hline Operation data & No. $=20$ \\
\hline \multirow{2}{*}{ Operation Time } & Mean \pm SD & $87.35 \pm 9.97$ \\
\cline { 2 - 3 } & Range & $70-110$ \\
\hline \multirow{2}{*}{ Blood loss } & Mean \pm SD & $294.00 \pm 133.51$ \\
\cline { 2 - 3 } & Range & $150-600$ \\
\hline \multirow{2}{*}{ Blood transfusion } & Negative & $18(90.0 \%)$ \\
\cline { 2 - 3 } & Positive & $2(10.0 \%)$ \\
\hline
\end{tabular}

The mean serum creatinine level of the patients before the operation was $0.9 \mathrm{mg} / \mathrm{dl}$ which increased to $1.03 \mathrm{mg} / \mathrm{dl}$ postoperatively, this difference was statistically insignificant $(\mathrm{P}=0.257)$. Also, the mean serum hemoglobin level of the Table (4): Laboratory data. patients before the operation was $13.32 \mathrm{~g} / \mathrm{l}$ which increased to $13.20 \mathrm{~g} / 1$ postoperatively, this difference was statistically insignificant $(\mathrm{P}=0.103)$. Changes of both serum creatinine and hemoglobin levels throughout the study are recorded in table (4).

\begin{tabular}{|c|c|c|c|c|c|c|}
\hline \multicolumn{2}{|c|}{ LABs } & Pre & Post & Test value & P-value & Sig. \\
\hline \multirow{2}{*}{ Creat } & Mean \pm SD & $0.99 \pm 0.29$ & $1.03 \pm 0.20$ & \multirow{2}{*}{-1.168} & \multirow{2}{*}{0.257} & \multirow{2}{*}{ NS } \\
\hline & Range & $0-1.3$ & $0.7-1.3$ & & & \\
\hline \multirow[t]{2}{*}{$\mathrm{Hb}$} & Mean \pm SD & $13.32 \pm 1.20$ & $13.20 \pm 1.23$ & \multirow[t]{2}{*}{1.716} & \multirow[t]{2}{*}{0.103} & \multirow[t]{2}{*}{ NS } \\
\hline & Range & $11.6-15.4$ & $11.20-15.3$ & & & \\
\hline
\end{tabular}

P-value $>0.05$ : Non significant (NS); P-value $<0.05$ : Significant (S); P-value $<0.01$ : highly significant (HS) $\quad \because$ Paired t- test

Tumor size proved to be an important parameter throughout the study. However, it had no significant statistical effect on the

results as regard operative or laboratory data. Co-relations are recorded in table (5).

Table (5): Effect of tumor size on operative and laboratory results.

\begin{tabular}{|l|c|c|}
\hline \multirow{2}{*}{} & \multicolumn{2}{|c|}{ Tumor Size } \\
\cline { 2 - 3 } & $\mathrm{r}$ & P-value \\
\hline Operation Time & 0.351 & 0.129 \\
\hline Blood loss & 0.133 & 0.576 \\
\hline Creat pre & 0.111 & 0.641 \\
\hline Creat post & 0.093 & 0.697 \\
\hline Hb pre & 0.115 & 0.629 \\
\hline Hb post & 0.126 & 0.596 \\
\hline
\end{tabular}

Other factors as tumor site (either upper polar, lower polar or mid-zonal), tumor growth pattern (either exophytic or endophytic) or even the nature of the dominant feeding branch (either single or multiple) could not build up any significant statistical difference throughout the study results. However, we could never ignore the importance of each from the practical point of view.
An important parameter which showed a direct relation with operative outcomes was the percentage of embolization. In fact, the 2 patients with relatively the most prolonged operative time who received blood transfusion due to considerable intraoperative bleeding seemed to have incomplete embolization as recorded in table (6). 
Table (5): Effect of percentage of embolization on operative results.

\begin{tabular}{|l|l|c|c|c|c|c|}
\hline \multicolumn{2}{|c|}{} & \multicolumn{2}{|c|}{ Percentage of Embolization } & Test value• & P-value & Sig. \\
\cline { 3 - 4 } \multicolumn{2}{|c|}{} & Incomplete & Complete & & & \\
\cline { 2 - 4 } & & & & & \\
\hline $\begin{array}{l}\text { Operati } \\
\text { on Time }\end{array}$ & Mean \pm SD & $102.50 \pm 10.61$ & $85.67 \pm 8.63$ & 2.581 & 0.019 & S \\
\cline { 2 - 4 } $\begin{array}{l}\text { Blood } \\
\text { loss }\end{array}$ & Range & $95-110$ & $70-105$ & & & \\
\cline { 2 - 4 } & Mange \pm SD & $575.00 \pm 35.36$ & $262.78 \pm 97.61$ & 4.399 & 0.000 & HS \\
\hline
\end{tabular}

P-value $>0.05$ : Non significant (NS); P-value $<0.05$ : Significant (S); P-value $<0.01$ : highly significant $(\mathrm{HS}) \cdot$ : Independent t-test

\section{DISCUSSION:}

Until the early 1990's, PN had been only performed when absolutely indicated in those patients with tumors in an anatomical or functional solitary kidney or for those with bilateral synchronous tumors. A relative indication for $\mathrm{PN}$ has been considered in patients with underlying medical conditions such that radical nephrectomy of the tumor bearing kidney would cause severe renal insufficiency ${ }^{(5)}$.

Recently, $70 \%$ of all newly diagnosed renal tumors are, in fact, small localized tumors with a median tumor size of $<4 \mathrm{~cm}$ (Tla). Approximately $20 \%$ of these tumors are benign neoplasms (i.e., oncocytoma, fat poor angiomyolipoma), $25 \%$ are indolent malignancies with limited metastatic potential (i.e., papillary type 1, chromophobe) and 54\% are the malignant clear cell carcinoma but at the T1 size $(<7$ $\mathrm{cm})$, metastasis would be realized in less than $10 \%$ of patients ${ }^{(6)}$.

Taken together, all these factors have led to the expansion of elective $\mathrm{PN}$ in patients undergoing resection of kidney tumor in the presence of a healthy contralateral kidney. PN has emerged as a greatly underutilized procedure that is often feasible even for central or hilar tumors, given adequate surgeon expertise $\mathrm{e}^{(7)}$.

Surgeons originally began to use RAE in the $1970 \mathrm{~s}$ to treat unresectable renal tumors that were symptomatic, since resection of such tumors has been associated with a high rate of peri-operative morbidity related to hemorrhage. RAE has continued to gain popularity for a variety of urologic conditions as treatment of angiomyolipomas, vascular malformations, medical renal disease, hemorrhagic complications following stone surgeries and complications following renal transplantation ${ }^{(8)}$.

In our study, we tried to focus on the potential role of RAE in enhancing NSS with a reliable safety profile avoiding long term adverse effects of intraoperative nonselective ischemia on renal function. 20 eligible patients with mean age $47.15 \pm$ 11.88 yrs (range 17 - 65) were enrolled in the study. Mean tumor size was $5.44 \pm 1.07$ $\mathrm{cm}$ (range $3.5-7$ ), mean operation time was $87.35 \pm 9.97 \mathrm{~min}$ (range $70-110$ ), mean blood loss $294.00 \pm 133.51 \mathrm{ml}$ (range $150-$ 600).

These results seems to be interesting when compared with the study accomplished by Patard et al. who studied patients with mean age at diagnosis of 59.1 - $12.9 \mathrm{yr}$ and mean tumor size was $3.4-2.1 \mathrm{~cm}$.

Blood transfusion rate was $15.3 \%$ and median blood loss was $350 \mathrm{ml}$ (range: 0$4000 \mathrm{ml}$ ). By analyzing 600 tumors measuring $<4 \mathrm{~cm}$ with both normal contralateral kidney and renal function, we found a $386 \mathrm{ml}$ mean blood loss. The need for blood transfusion was significantly increased in tumors $>4 \mathrm{~cm}$ in size (blood loss of $510 \mathrm{ml}$ for tumors measuring $>4$ $\mathrm{cm})^{(9)}$. 
In another study by Simone et al., 110 patients underwent PN after selective RAE for T1 renal tumors. Mean age of patients was 61 (range 37-80), and mean tumor size was $4.4 \mathrm{~cm}$. Mean operative time was 85 minutes (range 35-220), and mean blood loss was $306 \mathrm{~mL}$ (range 20-800). In one patient, RN was necessary because of the total intra-parenchymal growth of the tumor ${ }^{(10)}$.

No consensus on the use of RAE has been fashioned due to the small number of prospective studies comparing surgical resection combined with preoperative embolization versus surgery alone. Moreover, many large studies on the use of RAE were conducted in the $1980 \mathrm{~s}$, before the development of improved imaging modalities and embolization techniques and. To date, RAE has not been evaluated in a randomized controlled setting which has contributed to its underutilization $^{(11)}$.

\section{Conclusion:}

RAE has proved to be a very useful technique that is extremely underutilized in the field of renal tumor surgery may be partly due to lack of prospective studies which can outline benefits, precautions and proper definitions of success. RAE allows enhancement of surgical steps, preservation of renal function by avoiding non indicated ischemia. It may play a role in long term cancer control but a lot of studies are mandatory.

\section{REFERENCES:}

1. Siegel R, Jiemin $M$, Jemal A, et al: Cancer Statistics. CA Cancer J Clin 2014; 64:9-29.
2. Ljungberg B, Cowan NC, Hanbury DC, et al: $E A U$ guidelines on renal cell carcinoma: the 2010 update. Eur Urol 2010; 58:398-406.

3. Reinharta HA, Ghalebb $M$ and Davis BR: Trans-arterial embolization of renal tumors improves surgical outcomes: A case series. International Journal of Surgery Case Reports 2015; 15:116-118.

4. Li D, Pua BB and Madoff DC: Role of embolization in the treatment of renal masses. Semin Intervent Radiol 2014; 31:70-81.

5. Russo P: The role of surgery in the management of early stage renal cancer. Hematol Oncol Clin North Am 2011; 25:737-752.

6. Novick AC, Campbell SC, Belldegrun A, et al: Guideline for management of the clinical T1 renal mass. J Urol 2009; 182:1271-1279.

7. Russo $P$ and Mano R: Open mini flank partial nephrectomy: an essential contemporary operation. Korean J Urol 2014; 55:557-567.

8. Sauk $S$ and Zuckerman DA: Renal artery embolization. Semin Intervent Radiol 2011; 28:396-406.

9. Patard JJ, Pantuck AJ, Crepel M,et al: Morbidity and Clinical Outcome of Nephron-Sparing Surgery in Relation to Tumor Size and Indication. Eur Uro 2007; 52: 148-154.

10. Simone $G$, Papalia R, Guaglianone $S$, et al: Preoperative superselective transarterial embolization in laparoscopic partial nephrectomy: technique, oncologic, and functional outcomes. Journal of Endourology 2009; 23(9):1473-1478.

11. Davis $C$, Boyett $T$ and Caridi J: Renal artery embolization: application and success in patients with renal cell carcinoma and angiomyolipoma. Semin Intervent Radiol 2007; 24:111-116. 
دراسة استكثافية لفوائد استخدام الحقن الانسدادي الانتقائي للثرايين المغذية لأورام الكلى قبل جراحات الاستئصال الجزئي للكلى الانسدي

عبد الله أحمد عبد العال ، و محمد الغريب أبو المعاطي و محمود أحمد محمود ، وأحمد فاروق محمود ومحمد أحمد شعبان قسم جراحة المساللك البولية - كلية الطب - جامعة عين شمس

المستخلص

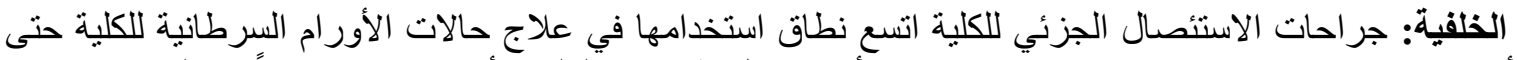

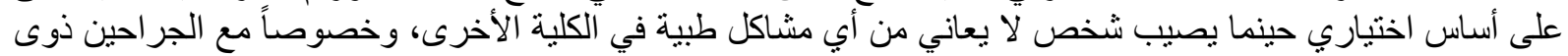

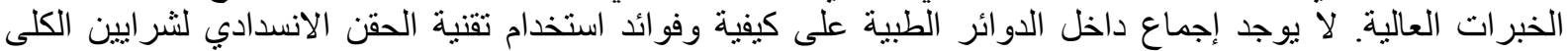

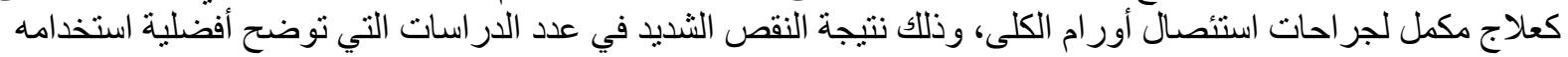
الههف من الدراسة: تقييم استخدام تقنيات الحقن الانسدادي الانتقائي للشر ايين المغذية لأور ام الكلى في تحسين كفاءة

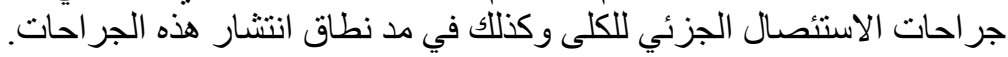

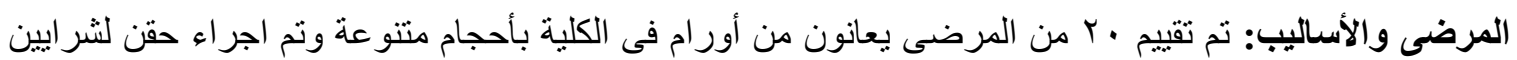

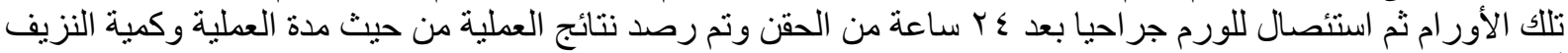

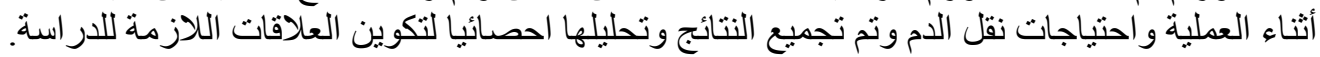

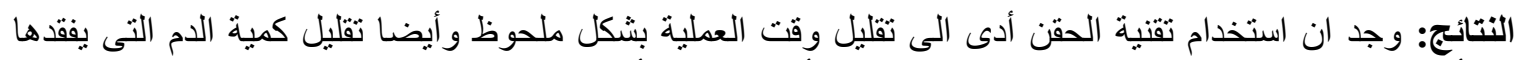
المريض أثناء الجر احة وبالتالى تقليل الحاجة الى نقل الدم أو مشتقاته وأدى الى تحسين كفاءة العطلية عن طريق تسهيل

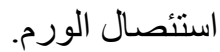

الاستتتاج: تعتبر هذه التقنية مفيدة الى حد بعيد فى تحسين كفاءة جر احات الاستئصال الجزئي للكلى و استئصسال أورام الكلى ولكنها تحتاج الى العديد من الدر اسات المستقبلية التى تؤكد أفضليتها وتحدد وسائل التطبيق الأمثل لها. 